\title{
PASIF GERME HAREKETLERININ SEDANTERLERDE OLUŞTURULAN GECIKMIŞ KAS AĞRISI ÜZERINE ETKILERI
}

\author{
Dilek İPEK ${ }^{1}$ Özgür ÖZKAYA ${ }^{2}$ Hasan SÖZEN ${ }^{2} \quad$ Atilla TEKAT $^{3}$
}

Geliş Tarihi: 10.09.2008

Kabul Tarihi: 18.02.2009

\section{ÖZET}

Bu çalışmanın amacı; pasif germe hareketlerinin, sedanterlerde yaratılan gecikmiş kas ağrısının elimine edilme süresi üzerine etkilerini araştırmaktır. Çalışma grubu yaş ortalamaları $21,26 \pm 3$ yıl olan, 26 sağlıklı ve gönüllü erkek Üniversite öğrencisinden oluşturuldu (germe; n=13, kontrol; n=13). Gecikmiş kas ağrısı oluşturmak için sağ bacağın hemstring kasları leg curll'de 5 set, 10 tekrarlık egzersizlerle çalıştırıldı. Germe grubuna set aralarında 30 saniye süreli üç setlik pasif germe egzersizleri uygulandı. Her iki gruptan da doku hasarında yükselme gösteren serum kreatin kinaz (Kk) enzimi ve nötrofil (NT) yüzde oranları antrenmandan önce ve sonra 6., 24. ve 48. saatlerde alınan kan örneklerinden analiz edildi. Antrenman sonrasında her iki gruba da 6., 24., ve 48. saatlerde Görsel Analog Skalası (GAS) uygulandı.

Alınan sonuçlara göre her iki grup için 6., 24. ve 48. saat NT yüzde oranları istatistiksel olarak anlamlı değildi ( $p>0.05)$. Fakat uygulanan pasif germe hareketleri, antrenman sonu 6., 24. ve 48. saat Kk seviyelerinde anlamlı bir düşüşe neden oldu (sırasıyla, $\mathrm{Kk}_{6}$; $\mathrm{t}=6.477, \mathrm{p}=.000 \mathrm{Kk}_{24} ; \mathrm{t}=5.140, \mathrm{p}=.000, \mathrm{Kk}_{48} ; \mathrm{t}=4.455, \mathrm{p}=.000$ ). GAS sonuçlarına göre 6., 24. ve 48. saat ağrı değerleri arasındaki fark da istatistiksel olarak anlamlıydı (sırasıyla, $\mathrm{GAS}_{6} ; \mathrm{t}=8.25, p=.000, \mathrm{GAS}_{24} ; \mathrm{t}=5.88, p=.000, \mathrm{GAS}_{48} ; \mathrm{t}=6.55, \mathrm{p}=.000$ ). Çalışmamızın sonuçlarına göre, uygulanan pasif germe egzersizlerinin kas hasarına bağlı ertelenmiş ağrıların azaltılmasında etkili olduğu görüldü.

Anahtar Kelimeler: Gecikmiş Kas Yorgunluğu, Pasif Germe Hareketleri

\section{THE EFFECT OF PASSIVE STRETCHING EXERCISES ON DELAYED ONSET MUSCLE SORENESS}

\begin{abstract}
The purpose of this study was to observe the effects of passive stretching exercises on delayed onset muscle soreness. A total of 26 healthy male university students $(21.26 \pm 3$ years) volunteered to participate study (13 stretching, 13 control). 5 set 10 repetition of strength training at Leg Curll was applied on hamstring muscles of right leg in order to cause delayed onset muscle soreness in volunteers. 3 sets of 30 second passive stretching technique were applied on the stretching group between the sets. The percentages of serum creatine kinase enzyme and neutrophil which increased in tissue injury related to delayed onset muscle soreness, were measured with the blood samples taken from both the groups before the training and 6,24 and 48 hours after the training. Visual Analog Scale (VAS) was applied on the subjects from both of the groups 6,24 and 48 hours after the training.

The results of this study, there was no significant difference on the percentages of neutrophil for $6^{\text {th }}, 24^{\text {th }}$ and $48^{\text {th }}$ hours measurement $(p>0.05)$. But, passive stretching exercises caused the decrease on the creatine kinase level for $6^{\text {th }}, 24^{\text {th }}$ and $48^{\text {th }}$ post training period (respectively, $t=6.477, p=.000 ; t=5.140, p=.000 ; t=4.455, p=.000$ ). VAS results was also significantly difference (respectively, $t=8.25, p=.000 ; t=5.88, p=.000 ; t=6.55, p=.000$ ). The results of our study; the elimination time of delayed pains depend on muscle soreness was positively effected passive stretching applications.
\end{abstract}

Key Words: Delayed Onset Muscle Soreness, Passive Stretching Exercises

\section{Giriş}

İskelet kaslarımız yüksek şiddette ve alışkın olunmayan tarzda yüklenmelere maruz kaldığında, ertesi gün neredeyse tüm vücudu saran bir ağrı tablosuyla karşılaşılır. Bu ağrı türü gecikmiş kas ağrısı (GKA) olarak adlandırılır. GKA oluştuktan sonra yapılan hareketler, kaslarda ağrıya, dokunmaya karşı hassasiyete ve sertliğe neden olur. Meydana gelen bu semptomların hissedilme süresi bir haftaya kadar uzayabilir (1).

\footnotetext{
1 Samsun Özel Atasam Hastanesi Fizik Tedavi ve Rehabilitasyon Bölümü

2 Ondokuz Mayıs Üniversitesi Yaşar Doğu Beden Eğitimi ve Spor Yüksekokulu

3 Ondokuz Mayıs Üniversitesi Tıp Fakültesi Cerrahi Tıp Bilimleri Anabilim Dalı
} 
Gecikmiş kas ağrısının sebeplerinin araştırılmaya başlandığı çalışmalar, 1900'lü yılların başlarına dayanır. Bu tür ağrıların kaynağının laktik asit adı verilen bir madde olduğu ve artan seviyelerinin bu tür ağrılara yol açtığı, o yıllarda ortaya atılmış ve en kabul görmüş teoridir $(1,2)$. Fakat günümüzde bu asidin nasıl oluştuğu, hangi sürelerde ve süreçlerle ortamdan uzaklaştırıldığı bilinmektedir. Dolayısıyla söz konusu ağrı türüyle ilişkili yakınmaların sebebinin laktik asit olmadığı açıktır (3).

GKA; yüksek şiddetli yüklenmeler sırasında oluşan yüksek germe potansiyeli nedeniyle, kas lifi içerisindeki zayıf miyofibrillerde oluşan mikro yırtıklar nedeniyle hissedilir. Bu yırtıklar kas dokusunda dolaşım bozukluğuna ve buna bağlı olarak ödeme neden olurlar. Devam eden reaksiyonların sonunda kasta ağrıyı tetikleyen iyon dengesizlikleri görülür (4).

Söz konusu şartlarda, serum Kk ve NT gibi kas ve kan enzimleri serbest kalır (5). Bu enzimler yapılan aktivitenin şiddeti ve dolayısıyla oluşan yıkımın büyüklüğüyle doğru orantılı seviyelerde serbestlenerek egzersiz sonrasında da yüksek seviyelerini korurlar (6). Dolayısıyla Kk ve NT oranı plazma konsantrasyonları, doku hasarının iyi bir göstergesidir (7). Bu tarz kan parametreleri, uygulanan bazı skalalar yoluyla non-invaziv olarak desteklenebilir (8).

Egzersizlere başlamadan hemen önce ve sonrasında doğru teknikle uygulanan pasif germe hareketleri; aktin ve miyozin elementlerinin üzerine düşen yükün daha etkili absorbe edilmesine yardımcı olur. Yan elastik yapıların egzersiz sırasında meydana gelen dirençlere karşı koyabilmesini kolaylaştırır. Sonuç olarak, iskelet kaslarının tonusu azalır ve kas liflerinde meydana gelen mikro yırtık riski en aza indirgenir (9). Ancak GKA oluşmuş ise germe hareketleri uygulanmamalıdır (10).

$\mathrm{Bu}$ çalışmanın amacı; egzersizlerden hemen sonra uygulanan pasif germe hareketlerinin, sedanterlerde yaratılan GKA üzerine etkilerini araştırmaktır.

\section{MATERYAL VE YÖNTEM}

\section{Araştırma Grubu:}

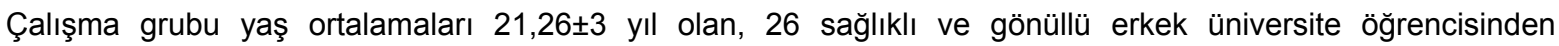
oluşturuldu (germe; n=13, kontrol; $n=13$ ).

\section{Verilerin Toplanması:}

Dinlenim Ölçümleri:

Sabah saat 08.00 sularında, Ondokuz Mayıs Üniversitesi Merkez Laboratuarında ilk kan alımları yapılarak dinlenim serum Kk ve \%NT oranları hesaplandı.

\section{Kas Hasarına Yol Açan Egzersiz Protokolü:}

Her katılımcının 10 tekrarlı maksimali Brzycki eşitliği (Brzycki Equation) kullanılarak tek tekrarlı maksimali hesaplanmak suretiyle saptandı [1RM $=$ Weight lifted $/(1,0278-$ (factor resulting in exhaustion $\times 0,0278)$ ]. Tek tekrarlı maksimallerin belirlenmesinin ardından, $1 / 3+(1,2 \mathrm{~kg})$ formülü ile her katılımcının 10 tekrarlı maksimali hesaplandı. Hesaplanan yüklerle, her katıımcının sağ bacağının Hemstring kası, klasik bir Leg Curll makinesi kullanılarak, 5 set-10 tekrarlı serilerle çalıştırıldı.

\section{Pasif Germe Egzersizleri:}

Her set bitiminde pasif germe gurubuna ait katılımcılara üçer set halinde her biri yaklaşık 30 saniye süren pasif germe egzersizleri yaptırıldı (Şekil 1).

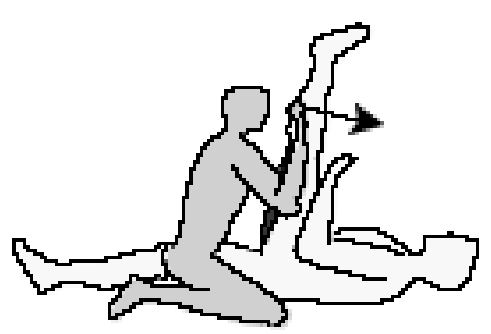

\section{Şekil 1: Pasif Germe Grubundaki Katılımcılara Kalça Fleksiyonu İle Uygulanan Germe Egzersizi}

\section{Egzersiz Sonrası Ölçümler:}

Her iki gruptan da 6., 24. ve 48. saatlerde kan örnekleri alınarak, serum Kk ve NT oranları ölçüldü. Bu ölçümler sırasında katılımcılara GAS uygulandı. Skala 10 santimetrelik bir doğrudan oluşturuldu ve üzerinde herhangi bir numaralandırma yapılmadı. Oluşturulan doğrunun sağ ucu hiç ağıı olmadığını, sol ucu ise kişinin dayanamayacak kadar ağrısı olduğunu tanımladı. Katılımcıların 6., 24. ve 48. saatlerde işaretlediği noktalar, daha sonra cetvelle ölçülerek sayısal değerlere dönüştürüldü. 
IPEK, D., ÖZKAYA, Ö., SÖZEN, H., TEKAT, A., "Pasif Germe Hareketlerinin Sedanterlerde Oluşturulan Gecikmiş Kas Ağrısı Üzerine Etkileri"

\section{Verilerin Analizi:}

Çalışma sonunda elde edilen veriler normal dağılıma uygunluk düzeyleri analiz edildikten sonra, farklılıkların analizi için eşleştirilmiş iki grup arasındaki farkların anlamlılık testi (Independent Smles t-test) ve bağımsız iki grup arasındaki farkların anlamlılık testi (Paired Samlpes t-test) kullanılarak değerlendirildi.

\section{BULGULAR}

Kuvvet uygulaması öncesi germe ve kontrol grubunun Kk değerleri (sırasıyla 115.92 \pm 21.55 ve 123.76 \pm 35.96 ) arasındaki fark istatistiksel olarak anlamlı değildi $(t=.675 ; p=.060)$.

6. saat Kk sonuçları incelendiğinde pasif germe hareketlerini uygulayan grubun değerlerinin, kontrol gruptan anlamlı ölçüde düşük olduğu görüldü (sırasıyla $143.15 \pm 12.24$ ve $256.46 \pm 61.87 ; t=6.477 ; p=.000$ ). Görülen fark 24 . ve 48. saatlerde de anlamlıydı $(p<0.001)$ ve giderek artan bir şekilde saptanmaya devam etti. 24 . saat Kk değerleri germe ve kontrol grupta sırasıyla $192.07 \pm 47.68$ ve $389.15 \pm 129.76(t=5.140 ; p=.000)$ olarak saptanırken, 48 . saat sonu değerleri sırasıyla $605.76 \pm 152.35$ ve $1894.69 \pm 1032.04(t=4.455 ; p=.000)$ olarak saptandı (Tablo 1).

Tablo 1- Araştırma Grubunun Kuvvet Uygulaması Öncesi ve 6., 24. ve 48. Saat Sonu Kk Değerleri

\begin{tabular}{|c|c|c|c|c|c|c|}
\hline \multirow[b]{2}{*}{ Dinlenim } & \multicolumn{2}{|c|}{ Pasif Germe Grubu (n=13) } & \multicolumn{2}{|c|}{ Kontrol Grubu (n=13) } & \multirow{2}{*}{$\begin{array}{c}\mathbf{t} \\
.675 \\
\end{array}$} & \multirow{2}{*}{$\begin{array}{c}\mathbf{p} \\
.060\end{array}$} \\
\hline & 115.92 & \pm 21.55 & 123.76 & \pm 35.96 & & \\
\hline 6. saat & 143.15 & \pm 12.24 & 256.46 & \pm 61.87 & 6.477 & .000 \\
\hline 24. saat & 192.07 & \pm 47.68 & 389.15 & \pm 129.76 & 5.140 & .000 \\
\hline 48. saat & 605.76 & \pm 152.35 & 1894.69 & \pm 1032.04 & 4.455 & .000 \\
\hline
\end{tabular}

NT oranı adına her iki grup için de her saat dilimi nötrofil değerleri arasındaki fark anlamlı saptansa da $(p<0.001)$, kuvvet uygulaması öncesi ve sonrasında 6., 24. ve 48. saatlerde ölçülen NT oranları arasındaki fark her iki grup için de istatistiksel olarak anlamlı değildi (Tablo 2).

Tablo 2- Araştırma Grubunun Kuvvet Uygulaması Öncesi ve 6., 24. ve 48. Saat Sonu NT Oranları

\begin{tabular}{|c|c|c|c|c|c|c|}
\hline \multirow[b]{2}{*}{ Dinlenim } & \multicolumn{2}{|c|}{ Pasif Germe Grubu (n=13) } & \multicolumn{2}{|c|}{ Kontrol Grubu (n=13) } & \multirow{2}{*}{$\begin{array}{c}\mathbf{t} \\
.137\end{array}$} & \multirow{2}{*}{$\begin{array}{c}\mathbf{p} \\
382\end{array}$} \\
\hline & 53.23 & \pm 9.18 & 53.69 & \pm 7.95 & & \\
\hline 6. saat & 61.46 & \pm 6.27 & 62.53 & \pm 6.42 & .432 & .669 \\
\hline 24. saat & 56.61 & \pm 7.74 & 56.76 & \pm 8.36 & .049 & .962 \\
\hline 48. saat & 60.92 & \pm 7.70 & 55.46 & \pm 8.47 & -1.719 & .098 \\
\hline
\end{tabular}

GAS sonuçları değerlendirildiğinde, her zaman dilimi için süre uzadıkça her iki grubun da değerlerinin anlamlı düzeyde artı̆̆ı saptandı $(p<0.001)$. Kuvvet uygulaması sonrası 6. saat GAS sonuçları değerlendirildiğinde pasif germe egzersizleri uygulayan grubun değerleri kontrol gruba oranla anlamlı ölçüde düşüktü (sırasıyla $0.23 \pm 0.22$ ve $1.75 \pm 0.62$; $\mathrm{t}=8.25, \mathrm{p}=.000)$. Her iki grupta 24. saat (sırasıyla $1.11 \pm 0.85$ ve $3.25 \pm 0.99 ; \mathrm{t}=5.88, \mathrm{p}=.000)$ ve 48 . saat $(2.83 \pm 0.80$ ve $5.12 \pm 0.97 ; \mathrm{t}=6.55, \mathrm{p}=.000$ ) sonuçları da germe grubu adına anlamlı düzeylerde düşük saptandı (Tablo 3).

Tablo 3- Araştırma Grubunun Kuvvet Uygulaması Sonrası ve 6., 24. ve 48. Saat Sonu GAS Sonuçları

\begin{tabular}{|c|c|c|c|c|c|c|}
\hline & Pasif Germe Grubu (n=13) & \multicolumn{2}{c|}{ Kontrol Grubu (n=13) } & $\mathbf{t}$ & $\mathbf{p}$ \\
\hline 6. saat & 0.23 & 0.22 & 1.75 & 0.62 & 8.25 & .000 \\
\hline 24. saat & 1.11 & 0.85 & 3.25 & 0.99 & 5.88 & .000 \\
\hline 48. saat & 2.83 & 0.80 & 5.12 & 0.97 & 6.55 & .000 \\
\hline${ }^{*} p<0.05$
\end{tabular}

\section{TARTIŞMA VE SONUÇ}

Gecikmiş kas ağrısının tedavisinde çeşitli yöntemler kullanılmaktadır. Bu yöntemlerin en sık kullanılanları; krioterapi, anti-inflamator ilaçlar, ultrason, elektriksel teknikler, homeopati, kompresyon, hiperbarik oksijen tedavisi ve masajdır (11). Bu tarz uygulamalara ek olarak; pasif germe hareketleri, spor uygulamalarındaki yeri ve uygulama kolaylığıyla değerlendirildiğinde, en etkili yöntem olarak ön plana çıkmıştır. Egzersiz öncesi ve sonrasında yapılan pasif germe hareketlerinin gecikmiş kas hasarına bağlı ağrıların önlenmesinde seçilecek en etkili yol olduğu belirtilmiştir (12). Smith ve arkadaşlarının (13), 1993 yılında yaptıkları bir araştırma raporuna göre, germe egzersizleri tek başına gecikmiş kas ağrılarının tüm belirtilerini ortadan kaldırma konusunda yeterlidir. Yine Smith ve arkadaşları (14), tarafından yapılan başka bir çalışmada; germe egzersizleri uygulanan bacağın, egzersiz uygulanmayan bacağa oranla harekete daha kuvvetli başladığı ve gecikmiş kas ağrısına bağlı sorunlardan daha az etkilendiği belirtilmiştir. Freiwald ve arkadaşlarının (15), 1998 yılında yaptıkları çalışmada; germe hareketlerinin fleksibilite ve gecikmiş kas ağrısının önlenmesi üzerine etkileri araştırımıştır. Egzersiz öncesinde yapılan bu tarz uygulamaların gecikmiş kas ağrısına bağlı sorunların 
azaltılmasında etkin olarak kullanılabileceği tavsiye edilmiştir. Wiemann ve Kamphöfner (16), 1995 yılında, germe çeşitlerinin gecikmiş kas ağrısı üzerine etkilerini araştırdıkları çalışmalarında; 3 set, 30 saniye süreyle yapılan kısa süreli germe hareketlerinin, kas hasarı oluşma ve sakatlanma riskini azalttığını saptamışlardır. Yine aynı çalışmanın sonuçlarına göre, GKA'nın giderilmesinde kullanılabilecek en iyi gerdirme yönteminin pasif gerdirme olduğu iddia edilmiştir. Germe egzersizlerinin kas kasılmaları sırasında mikro düzeyde görülen kas hasarlarının oluşma ihtimalini azalttığı ve kas tonusunu düşürdüğü ortaya konmuştur (17).

Kas hasarı oluştuğunda başta Kk olmak üzere bazı enzimler serbestlenir. Kk depoları oldukça sınırıdır fakat kas kasılmasının erken evreleri için gerekli ATP seviyelerinin devamlılığını sağlamak için çabukça üretilirler. Plazma Kk seviyeleri, kas hasarının boyutunun bir göstergesidir. Dışarıdan alınacak bir darbe bile, bu tarz enzimlerin kan seviyelerinin artmasına neden olabilir (18). Bu çalışmada pasif germe hareketlerinin GKA'nın elimine edilme süresi üzerine etkisi araştırılmıştır. Bu etkinin analizinde kullanılan ve birincil ölçüt parametresi olarak kabul edilen serum Kk değerleri adına; germe ve kontrol grubun 6., 24. ve 48. saat sonu değerleri anlamlı ölçüde farklı saptanmıştır. Görülen fark her ölçümde giderek belirginleşerek, 48. saat sonunda en yüksek sayısal değere ulaşmıştır $(p<0.001)$. Saptanan değerler yıkımın yaratılığı kuvvet uygulaması sonrası germe hareketleri yapan grup adına anlamlı ölçüde düşük bulunmuştur $(p<0.001)$. Ancak serum Kk değerlerini desteklemek adına kullanılan ve ikincil ölçüt parametresi olarak kabul edilen NT oranı arasındaki fark her iki grup için de istatistiksel olarak anlamlı değildir ( $p>0.05)$. GAS sonuçları da Kk sonuçlarına benzer bir tablo sunmuştur. Germe grubu adına değerler 6., 24. ve 48. saatlerde anlamlı ölçüde düşük saptanmıştır $(p<0.001)$.GAS sonuçları adına her iki grup için de görülen farkın yine saat ilerledikçe belirginleştiği söylenebilir $(p<0.001)$. Çalışmamızda ilgili etkinin araştırımasında kullanılan GAS sonuçları adına, test sonu değerlerin non-invaziv bir ölçüt kriteri olduğu iddia edilebilir. Ancak bu tarz skalalar, çalışma sonuçlarını desteklemek adına kullanılan oldukça yaygın ölçüm araçları olarak kabul edilmektedir (19).

Aksini iddia eden sınırı literatüre karşın $(19,20,21,22)$, çalışmamızın sonuçları ve ilgili literatürün ağırlıklı kısmı değerlendirildiğinde; pasif germe hareketlerinin, kas hasarına bağlı ağrıların giderilmesinde oldukça etkili bir yöntem olduğu söylenebilir. Isınma periyodunda ve antrenman dahilinde gerek görülen her an stretching uygulamaları tavsiye edilen ve GKA oluşma riskini azaltan uygulamalar olarak önerilmektedir.

\section{KAYNAKLAR}

1. Szyman, D.J., Recommendation for the avoidance of delayed onset muscular soreness, Strength and Conditioning Journal, 23(4), 7-13. 2000

2. Hollman, W., Hettinger, T., Sportmedizin.4. Aufl. Schattauer, Stutgart, New York. 239-240, 2000

3. Dierking, J.K., Bemben, M.G., Delayed onset muscle soreness, Strength and Conditioning Journal, August, $44-47$, 1998

4. Böning, D., Aktuelles zum Muskelkater. Sportortopedie, Sporttraumatol 11: 167-170, 1995

5. Gleeson, M., Almey, J., Brooks, S., Cave, R., Lewis, A., Griffiths, H., Haematological and acute-phase responses associated with delayed onset muscle sorenessin humans. Europen Journal of Applied physiology, 71, 2-3, 137-142, 1995

6. Murray, R.K., Gramer, D.K., Mayers, P.A., Rodwell, V.M., Harper'sBiochemistry, Tweety Second Edition, Appleton\& Lange,San Mateo, CA/ Norwalk,CT, 1991

7. Champe, P.C.,Harvey, R.A., Biyokimya, İkinci baskı, Nobel Kitapevleri, İstanbul, 1997

8. Price, DD., McGarth, PA., Rafil, A., Buckinghon, B., The validation of visual analoge scales as ratio scale measures for cronic and experimental pain. 18(3), 1717-2220, 1983

9. Ullrich,K., Gollhafer,A., Physiologische aspekte und effectivitat unterschiedlicher dehnmethoden. Deutsche Sportmedizin für Sport. 45, 336-345, 1994

10. Glück, S., Schwarz, M., Hoffman, V., Wydra, G., Bewegungsreichweite, zugkraft und muskelaktivitat bei eigen-bzw. Fremdregulierter dehnung. Deutsche Zeitschrift für Sportmedizin. 53(3), 2002

11. Hilbert, J. E., Sforzo, G. A., Swensen, T., The effects of massage on delayed onset muscle soreness, British Journal Of Sports Medicine, 37(1), 72 - 4. London, 2003

12. Böning, D., Muskelkater. Institut für Sportmedizin, Universitatklinikum Benjamin Franklin, Freie Universitat Berlin. Deutsche Zeitschrift für Sportmedizin. 51(2), 2000

13. Smith, L.L., Brunetz, N.H., Chenıer,T.C., McCammon, M.R., Houmard, J.A., Franklın, M.E., Israel, R.G., The effects of static and ballistic tretching on delayed onset muscle soreness and creatin kinase, Res quart for Exerc\& Sport Vol.64, 103-107, 1993

14. Smith, L.L., Keatin, M.N., Holbert, D., Spratt, D.J., McCammon, M.R., Smith, S.S., Israel, R.G., The effects of athletic massage on delayed onset muscle soreness, creatine kinase, and neutrophil count: a preliminary report. Journal Orthop Sports Physical Ther, 19(2), $93-9,1994$

15. Freiwald, J., Engelhardt, M., Gnewuch, A., Streching possibilities and limits, Ther Umsch Apr:55(4), 267-273, 1998

16. Wiemann, K., Kamphöfner, M., Verhindert statisches dehnen des auftreten von muskelkater nach exentrischem traininig?, Deutsche Zeitschrift für Sportmedizin, 46(9), 411-421, 1995

17. Bach,I., Dehnen/ Streching FG/K/E WS / 2003-01-20, 2002

18. Jenkinson, A., Muscle Soreness and Damage, SR, 2002

19. Herbert, R.P., Gabriel, M., Effects of tretching before and after exercising on muscle soreness and risk of injury, Systematic review, BMJ, 325,1-5, 2002

20. High, D.M., Howley, E.T., Franks, B.D., The effects of static tretching and warm-up on prevention of delayed muscle soreness, Res.quart. for Exer \& Sport, 60, 357-361, 1989

21. Lund, H., Vestergaard-Poulsen, P., Kanstrup, I.L., Sejrsen, P., The effect of passive tretching on delayed onset muscle soreness, and other detrimental effects following eccentric exercise, Scand J Med Sci Sports, 8(4), 216-21, 1998

22. Wiemeyer, J., Dehnen eine sinnvolle vorbereitungsmassnahme im sport. Spektrum der Sportwissenschaften, 14(1), 53-80, 2002 